\title{
TWO-PHASE ANAEROBIC DIGESTION OF MUNICIPAL ORGANIC SOLID WASTES
}

F. Ramírez-Vives ${ }^{1}$, R. Rodríguez-Pimentel ${ }^{1,3}$, A. de Jesús-Rojas ${ }^{1}$, F. J. Martínez-Valdez ${ }^{1}$, S. Rodríguez-Pérez ${ }^{2}$, and O. Monroy-Hermosillo ${ }^{1}$

'Biotechnology Department, Universidad Autónoma Metropolitana, Av. San Rafael Atlixco 186, Col. Vicentina, 09340 Iztapalapa, D.F, Mexico

frav@xanum.uam.mx, isabelropi@hotmail.com,antoninarojas@yahoo.com.mx, fco.jav.mv@gmail.com,monroy@xanum.uam.mx,

${ }^{2}$ Chemistry Department, Universidad de Oriente, Patricio Lumumba s/n, C.P. 223.0.06824, Santiago de Cuba. suyen@cebi.uo.edu.cu

${ }^{3}$ Division of environmental technology, Universidad Tecnológica de Nezahualcóyotl, circuito universidad tenológica S/N Col. Benito Juárez, C.P. 57000 Nezahualcoyotl, Edo.de México

\begin{abstract}
Two stages anaerobic digestion of the organic fraction of municipal solid wastes (OFMSW) is proposed using a batch anaerobic trickling bed (BATB) reactor in the first hydrolysis and acidogenesis stage. At total solids loading of $135 \mathrm{~g} / \mathrm{L}$ and reaction times around 30 days, total solids (nTS) and chemical oxygen demand (nCOD) removal efficiencies above $46 \%$ were obtained independently of $\mathrm{pH}$ (between 4.1 and 6.4). Dependent on $\mathrm{pH}$ were methane production, four times more at $\mathrm{pH} 6.4$ than at 4.8 and four times more volatile fatty acids (VFA) production at 6.4 than at 4.1 and twice than at 4.8. Leachates generated in the BATB reactor were diluted with municipal wastewater and fed to an upflow anaerobic sludge blanket (UASB) reactor at volumetric organic loading rates from 11 to $28 \mathrm{~g} / \mathrm{L} . \mathrm{d}$ where $90 \%$ COD removal efficiencies

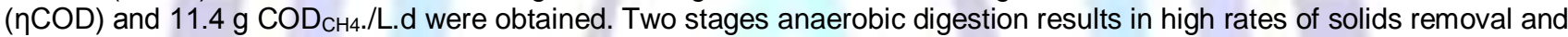
methane production $(0.63 \mathrm{kWhr} / \mathrm{kg}$ TS fed).
\end{abstract}

\section{Indexing terms/Keywords}

Organic solid wastes, trickling bed, leachate, hydrolysis , methanogenesis

\section{Academic Discipline And Sub-Disciplines}

Biothecnology

\section{SUBJECT CLASSIFICATION}

Digestión anaerobia

\section{TYPE (METHOD/APPROACH)}

Experimental

\section{Council for Innovative Research}

Peer Review Research Publishing System

\section{Journal: JOURNAL OF ADVANCES IN BIOTECHNOLOGY}

Vol 3., No 2.

www.ciribt.org , jbteditor@gmail.com 


\section{INTRODUCTION}

The total generation of municipal solid wastes in Mexico reached 40 million tons in 2010, where the organic fraction (OFMSW) was $53 \%$. Only $56 \%$ of these wastes ended up in landfills, $11 \%$ were deposited in rustic landfills and the remaining $33 \%$ in uncontrolled places or clandestine landfills [1]. Landfilling in Mexico is not a sustainable alternative to dispose of the OFMSW because due to the extended treatment area they need can only be located in the outer reaches of the cities where transportation of wastes is expensive and use of delayed and uncontrolled methane production is inefficient.

Alternatively, two stage anaerobic digestion of OFMSW in compact and controlled reactors is a sustainable treatment, because they can be installed in small plants within the cities reducing transportation costs and using in the surroundings methane, to produce enough energy to carry out the entire management of the municipal solid wastes [2].

In the first acidogenic stage the high concentration of fermentable matter in the OFMSW will produce rapidly high concentrations of volatile fatty acids (VFA) at $\mathrm{pH}<6$. In a second methanogenic stage these VFA can be transformed to methane in an upflow anaerobic sludge bed (UASB) reactor.

Two stages AD of OFMSW using batch stirred tank reactors for the hydrolytic-acidogenic phases have been studied. Vieitez and Ghosh, showed that acidogenesis is inhibited at $13 \mathrm{~g}$ VFA. $\mathrm{L}^{-1}$ [3], although Dinamarca et al., obtained more than $25 \mathrm{~g}$ VFA. $\mathrm{L}^{-1}$ in $\mathrm{pH}$ uncontrolled reactors [4].

Using a leaching bed reactor, AD two stages was studied by Chungh et al., Šan \& Onay, Zhang et al., Chen et al., Demirer \& Chen, $\mathrm{Xu}$ et al. They all recycled part of the leachate (the first two using bulking agents to aid percolation through the solids bed) and found that when buffered, the VFA production was increased [5-10]. There are reports that $\mathrm{pH}$ affects the hydrolysis first-order constant, $[8,11]$.

Hence, this step must be hastened. On the other hand, when hydrolysis is accelerated, the VFA may accumulate to a level that is inhibitory to methanogenic and acidogenic microorganisms, $[12,13]$. Moreover, build up of VFA level depresses the $\mathrm{pH}$ level of the liquid, a condition which decreases the hydrolysis rate of proteins and lipids that are present in the OFMSW [14]. Elango et al. reported that high TS and COD removal are enhanced by neutral $\mathrm{pH}$ [15].

The leachates are then treated in UASB reactors, at loading rates from 6 to $32 \mathrm{~g} \mathrm{COD} \cdot \mathrm{L}^{-1} \cdot \mathrm{d}^{-1}$ and concentrations from 0.2 to $60 \mathrm{~g} \cdot \mathrm{L}^{-1}$, to obtain COD removal efficiencies (nCOD) higher than $90 \%$ buffering the leachates to $\mathrm{pH} 7$ and supplementing phosphorus [16, 17].

Tran et al. [18], evaluated the AD of OFMSW a two-phase system composed of a fed-batch hydrolysis-acidogenesis reactor (phase I) and a methanogenic Upflow Anaerobic Sludge Blanket (UASB) reactor (phase II). Feeding the first reactor $2 \mathrm{~kg}$ of OFMSW with $0.5 \mathrm{~L}$ of water, the leachate generated is fed to a UASB, adjusting the pH when necessary and with the addition of nutrients. They worked with organic load rate (OLR) of $1.48 \mathrm{kgCOD} \cdot \mathrm{m}^{-3} \cdot \mathrm{d}^{-1}$ and $2.87 \mathrm{kgCOD} \cdot \mathrm{m}^{-3} \cdot \mathrm{d}$ 1. COD removals obtained $47.5 \%$ of the total COD present in the feed OFMSW and the highest methane generation rate was $2.6{\mathrm{~L} . \mathrm{d}^{-1}}^{\text {or }} 6.6 \mathrm{~g} \mathrm{CH}_{4}-\mathrm{COD} \mathrm{d}{ }^{-1}$.

All the reported two stage processes are based on the use of water, to obtain slurries to produce VFA which need to be neutralized and supplemented with nutrients in order to be methanized. For these reasons this study aimed to evaluate the anaerobic digestion in two stages of OFMSW (15\% TS): hydrolysis and acidogenesis in a batch anaerobic trickling bed (BATB) reactor to maintain the normal humidity of the OFMSW by trickling of a small amount MWW over the solids bed; and acetogenesis and methanogenesis of the leachate, diluted as needed with MWW, in a UASB reactor (figure 1), in order to use the waste generated in cities.

\section{MATERIALS AND METHODS OFMSW samples}

OFMSW were collected from households and stored at $5^{\circ} \mathrm{C}$ from one to four days before being fed to the reactors. It was composed of a mixture of fruit residues (melon, papaya, watermelon, pineapple, mango, cucumber, orange, lemon, grapefruit, banana, apple, peach, avocado), vegetables (tomato, spinach, chard, hibiscus flowers, zucchini, peppers, carrots, purslane, parsley, cilantro, onion), processed foods (egg, egg shell, rice, sausage, ham, cheese, tortilla, bread, pasta) and garden wastes. The samples were ground to a particle size of 1-5 mm prior to feeding the hydrolytic reactor batch.

\section{Batch Anaerobic trickling bed (BATB) reactor}

Three $4 \mathrm{~L}$ propylene cylindrical containers $(\mathrm{D}=16 \mathrm{~cm}, \mathrm{H}=17 \mathrm{~cm}$ ) were loaded with batches of $3.5 \mathrm{~kg}$ of ground OFMSW (Table 1) forming beds of $14 \mathrm{~cm}$ high with particle sizes between 1 and $5 \mathrm{~mm}$. Municipal wastewater with COD concentrations around $0.3 \mathrm{~g} \mathrm{~L}^{-1}$ was fed to the beds at a rate of $25 \mathrm{mLL}^{-1} \cdot \mathrm{d}^{-1}$ (Fig 1), maintaining the normal humidity of the OFMSW by trickling a small amount of municipal wastewater (MWW) over the solids bed.

One of the reactors $\left(R_{w}\right)$ was operated only with MWW. In the other two reactors $\left(R_{w L 7}\right.$ and $\left.R_{w L}\right), 10 \%$ of the leachate (2.5 $\mathrm{mL} \cdot \mathrm{L}^{-1} \cdot \mathrm{d}^{-1}$ ) was recycled, together with $22.5 \mathrm{mll}^{-1} \cdot \mathrm{d}^{-1} \mathrm{MWW}$, buffered to $\mathrm{pH} 7$ and without buffer, respectively. The leachate was collected from the bottom exit of the reactor (figure 1). Biogas was measured by volume displacement in a brine column to avoid gas dissolution. The first batch runs were inoculated with $0.4 \mathrm{~L}$ of granular sludge $\left(52 \mathrm{~g}^{\cdot} \mathrm{VSS} \mathrm{L}^{-1}\right.$ and a 
methanogenic activity of $0.6 \mathrm{~kg} \mathrm{CH}_{4} \mathrm{COD} \mathrm{kg}^{-1} \mathrm{VSS}^{-1}$ ) obtained from a UASB reactor treating a malting plant wastewater. Successive batches were inoculated with $10 \%$ of the residual solids of the previous batch.

\section{UASB reactor.}

Leachates from BATB reactors and MWW $\left(300 \mathrm{mgCODL}^{-1}\right)$, were treated in $2.2 \mathrm{~L}(\mathrm{D}=8.4 \mathrm{~cm}$ y $\mathrm{H}=40 \mathrm{~cm})$ UASB reactors inoculated with $0.5 \mathrm{~L}$ of the granular sludge $\left(52 \mathrm{~g} . \mathrm{VSS} . \mathrm{L}^{-1}\right.$ and a methanogenic activity of $0.6 \mathrm{~kg} \mathrm{CH}_{4} \mathrm{COD}^{\mathrm{kgg}}{ }^{-1} \mathrm{VSS}^{-\mathrm{d}^{-1}}$ ).

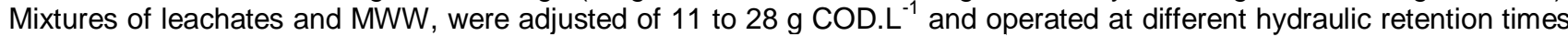
(HRT):, 1, 1.25 and 1.5 days. Biogas was measured as described in section 2.

\section{Analysis of reactors}

Figure 1 shows the setup of the BATB and UASB reactors. A batch of OFMSW is trickling down with a small amount of MWW $\left(S w=0.3 \mathrm{~g} \cdot \mathrm{L}^{-1}\right)$ to solubilize solids and the leachate rich in soluble COD is diluted with MWW $\left(F_{L} . S_{L}+F w . S w=\right.$ $\mathrm{F}_{\left.\mathrm{U}_{0} . \mathrm{S}_{\mathrm{U}}\right)}$ ) to feed a UASB reactor to produce methane.

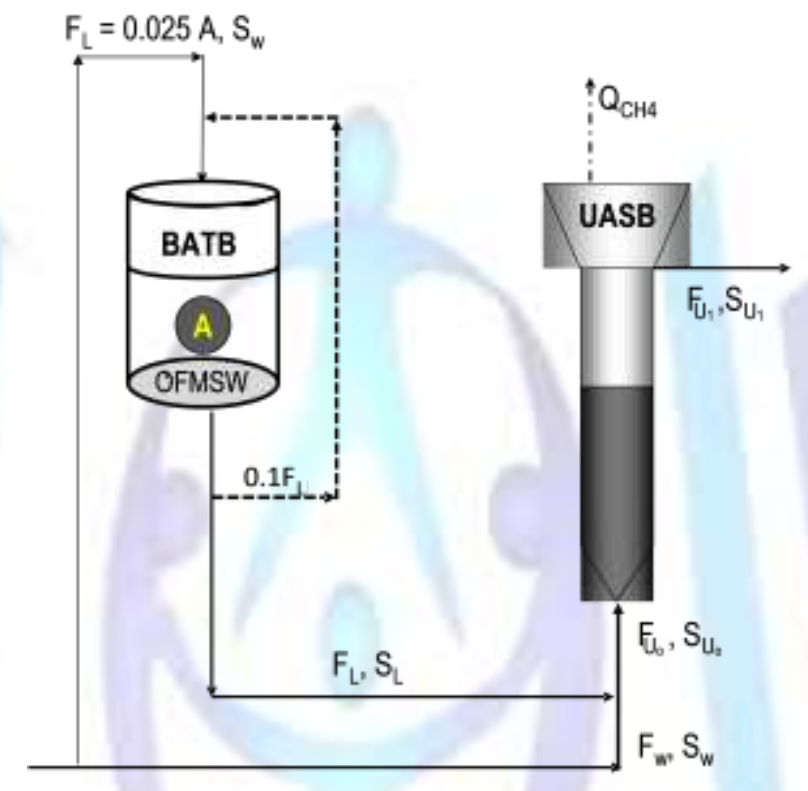

Figure 1. Anaerobic trickling bed batch (BATB) reactor treating the organic fraction of the municipal solid waste (OFMSW) together with municipal wastewater. F: flow rates [L.d ${ }^{-1}$ ], S: COD concentrations [g. $\mathrm{L}^{-1}$ ]. Subindexes: $\mathbf{\text { , }}$ $L$, $U$,: wastewater, leachate and UASB respectively. 0 , entrance, 1 out .

Equation 1 is the COD balance in the first reactor. COD input minus output minus the amount which is dissolved, $\mathrm{r}_{\mathrm{S}}=\mathrm{k}\left(\mathrm{S}_{0}{ }^{*}\right.$ $\left.-S_{L}\right)$.

$$
\mathrm{V} \frac{\mathrm{dS}_{\mathrm{L}}}{\mathrm{dt}}=\mathrm{F}_{\mathrm{L}}\left(\mathrm{S}_{\mathrm{sy}}-\mathrm{S}_{\mathrm{L}}\right)-\mathrm{Vr}_{\mathrm{S}}
$$

$$
\frac{d S_{L}}{d t}=-D S_{L}-k\left(S_{\circ}^{*}-S_{L}\right)-V r_{S}
$$

Where

$\mathrm{V}=$ volume of the OFMSW [L],

$\mathrm{S}=\mathrm{COD}$ concentration [mg COD. $\left.\mathrm{L}^{-1}\right]$,

$\mathrm{F}=$ leachate flow $\left({\mathrm{L} . \mathrm{d}^{-1}}^{-1}\right)$,

$\mathrm{D}=$ the dilution rate $=\mathrm{FL} \cdot \mathrm{V}^{-1}\left[\mathrm{t}^{-1}\right]$,

$\mathrm{k}=$ the dissolution specific constant $\left[\mathrm{t}^{-1}\right]$,

Indexes: * at the OFMSW, L at the leachate, 0 initial, $w$ at the MWW. 
Integration of equation 1 with $(S w-S L)=-S L$ (as $S w$ is negligible compared with $S L$ ) taking as boundary conditions; when $t$ $=0, \mathrm{SL}=\mathrm{S}^{\star} \mathrm{O}$, results in:

$$
S_{L}=\frac{S_{0}^{*}}{D-k}(D * \exp (-D-k) * t)-k
$$

The performance of the UASB reactor at different organic loading rates $\left(B_{v}=S_{U o} / H R T\right)$ is measured as the COD removal efficiency $\left(n_{s}\right)$ which in turn is a measure of the COD removal rate $\left(r_{s}=\eta_{C O D} \cdot B_{v}\right)$ and a plot of several sets of values is used to determine the maximum loading rate at which the $r_{s}$ decreases beyond an acceptable value.

\section{Statistical analysis}

The specific dissolution constant $(k)$ was estimated by fitting equation 2 to experimental data using Polymath 4.1 . Data from the different runs were analyzed by one way ANOVA with Tukey-Kramer Comparison Test at $\mathrm{P}<0.05$.

\section{Analytical methods}

The $\mathrm{pH}$ was determined with potentiometric equipment HANNA HI 255. Alkalinity, COD, TSS, VSS and FSS, were determined by standard methods, [19]. COD in OFMSW was measured in $1 \mathrm{~g}$ ground samples, suspended in distilled water $(0.1 \mathrm{~L})$, and processed in the same way as the leachate samples. For VFA analysis, a $1.5 \mathrm{~mL}$ sample was taken and centrifuged at $1,120 \mathrm{G}$ for $15 \mathrm{~min}$. The supernatant was filtered. A $950 \mu \mathrm{L}$ aliquot was acidified with $50 \mu \mathrm{L}$ of $\mathrm{HCl} 2.2 \mathrm{M}$. and determined with a HP 5890 gas chromatograph with flame ionization detector (FID) with an AT 1000 capillary column using nitrogen as carrier gas at $4.5 \mathrm{~mL} \mathrm{~min}^{-1}$, injector temperature $250^{\circ} \mathrm{C}$, detector temperature $200^{\circ} \mathrm{C}$, with a ramp of $25^{\circ} \mathrm{C} \min ^{-1}$.

Biogas composition was determined using a gas chromatograph (GowMAC 580 series), with a thermal conductivity detector (TCD) operating at the following conditions: Column, detector and injector temperatures: $140^{\circ} \mathrm{C}, 190^{\circ} \mathrm{C}$, and $170^{\circ} \mathrm{C}$, with a ramp of $25^{\circ} \mathrm{C} \mathrm{min}^{-1}$. The column was packed with Carbosphere $80 / 100$, using as Helium as carrier gas at 40 psi pressure, flow rate: $25 \mathrm{~mL} \mathrm{~min}^{-1}$, polarity: $120 \mathrm{~mA}$.

\section{RESULTS AND DISCUSSION OFMSW characterization}

Table 1 shows the OFMSW characterization of thirteen loads to the three BATB reactors. A COD value $\left(1.57 \mathrm{kgCOD}^{\mathrm{kg}}{ }^{-1}\right.$

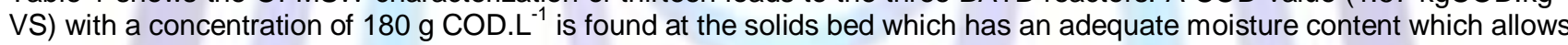
for an anaerobic degradation, [20]. With the low void space only a small volume of water can trickle down the bed without the risk of flooding it and with no need for bulking agents to enhance percolation as suggested Xu et al. [10].

Table 1. Characterization of the OFMSW and MWW (n=13)
\begin{tabular}{|c|c|c|}
\hline Parameter & Units & OFMSW \\
\hline Initial pH & & $5.5 \pm 0.2$ \\
\hline Void space & $\%$ & $14 \pm 1.16$ \\
\hline Density & $\mathrm{g} \mathrm{cm}^{-3}$ & $0.88 \pm 0.03$ \\
\hline Moisture & $\%$ & $84.6 \pm 2.2$ \\
\hline TS & $\mathrm{gkg}^{-1}$ & $154 \pm 0.4$ \\
\hline VS & $\mathrm{gkg}^{-1}$ & $130 \pm 0.3$ \\
\hline FS & $\mathrm{gkg}^{-1}$ & $24 \pm 0.1$ \\
\hline COD & $\mathrm{gL}^{-1}$ & $180 \pm 60$ \\
\hline Proteins & $\mathrm{gkg}^{-1}$ & $15 \pm 5$ \\
\hline Carbohydrates & $\mathrm{gkg}^{-1}$ & $27 \pm 17$ \\
\hline C/N & & $14.87 \pm 1.77$ \\
\hline
\end{tabular}

\section{Hydrolysis and acidogenesis of the OFMSW}

Figure 2 shows the dissolved COD of the OFMSW leachates of the three reactors $\left(R_{w}, R_{w L 7}\right.$ and $\left.R_{w L}\right)$. Three phases can be distinguished, an initial lag phase of 10 days, a decaying phase of approximately 20 days and a final stabilization phase of 15 days. After an initial COD in leachate $\left(\mathrm{S}_{\mathrm{L}}\right)$, lower than the So* of solids $\left(180 \mathrm{gL}^{-1}\right)$, there is a lag of about ten days where the leachate concentration does not decrease. This is probably due to a large amount of soluble material, already 
present in the organic wastes, which slowly washes away due to the small amount of water used. This lag time might be reduced by mechanically dewatering the solid. After this moment, the material which is solubilized due to hydrolysis and acidogenesis, start to leach away and SL starts to decrease (equations 1 and 2) until about 30 days after which, it remains constant. The prediction of SL with equation 2, using the mean of the calculated dissolution constants (Table 2), is plotted for each reactor. The fit suggests that this balance can be used to study this kind of reactors.

$\mathrm{Rw}$

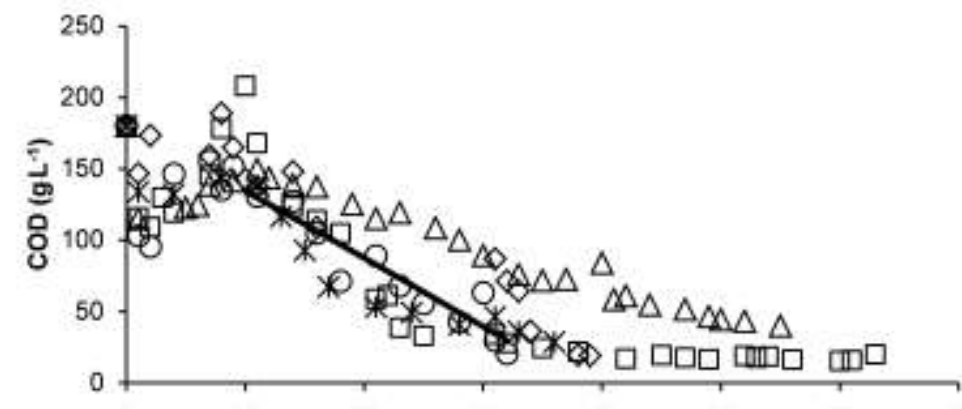

RwL7
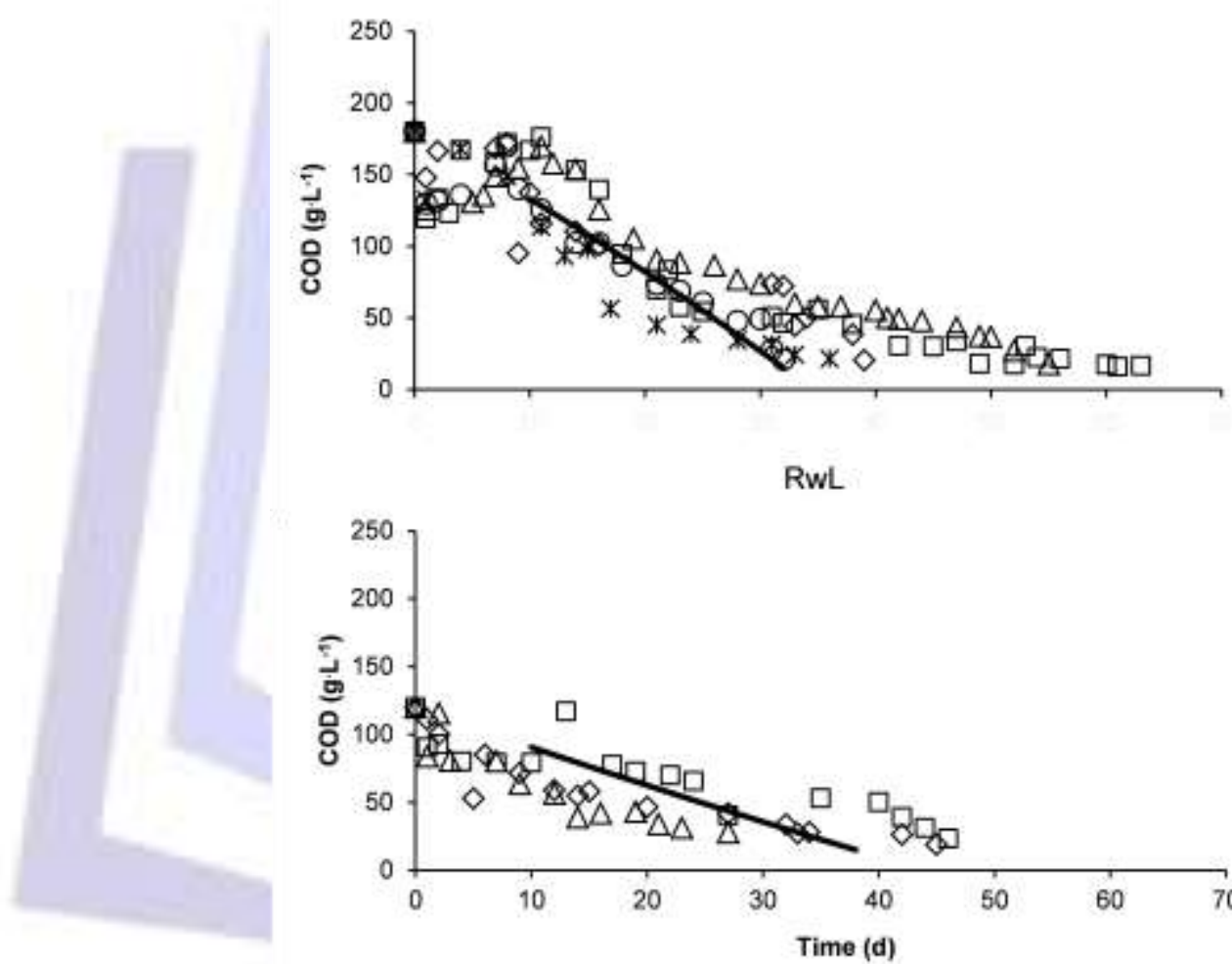

RwL
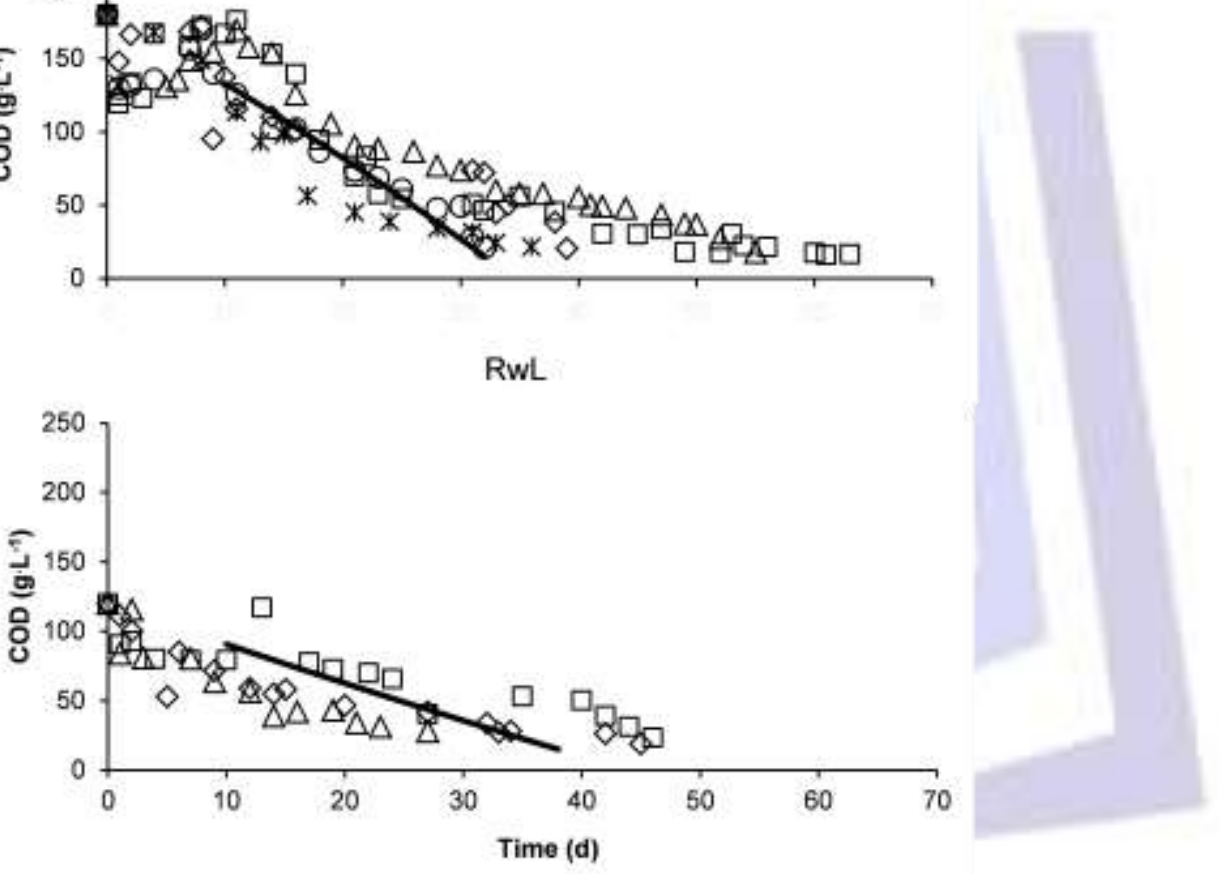

Figure 2. Leachate COD from BATBR at three different conditions. Rw leached with MWW, RwL7 recycling $10 \%$ of leachate and buffered at pH 7 and RwL same as the latter but without pH buffer. ( $\square$ first, $\diamond$ second, $\Delta$ third, o fourth, * fifth runs, plot of equation 2 using the average $\mathrm{k}$ )

Table 2 shows average values of other important results: leachate $\mathrm{pH}$, VFA content, biogas production $\left(\mathrm{Q}_{\mathrm{bg}}\right)$ and the removal efficiencies of solids ( $\left.\eta_{\mathrm{TS}}\right)$ and COD ( $\left.\eta_{\mathrm{COD}}\right)$. The effect of recycling part of the leachate can be assessed by comparing the $\mathrm{pH}$ of $\mathrm{R}_{\mathrm{w}}$ and $\mathrm{R}_{\mathrm{wL}}$ reactors. The lower $\mathrm{pH}$ of the latter negatively impacted on VFA and $\mathrm{CH}_{4}$ formation. By recycling only $10 \%$ in $R_{w L 7}$ four times as much VFA as in $R_{w L}$ was obtained. 
Table 2. Response variables of hydrolysis and acidogenesis of OFMSW in BATB reactor

\begin{tabular}{|c|c|c|c|c|c|c|c|c|}
\hline \multirow{3}{*}{ Run } & \multicolumn{3}{|c|}{ Leacheate } & \multicolumn{5}{|c|}{ OFMSW bed } \\
\hline & \multicolumn{2}{|c|}{$\mathrm{pH}$} & \multirow{2}{*}{$\begin{array}{c}\text { VFA } \\
\text { VFA }^{-} \text {COD }^{-1} \mathrm{deg}\end{array}$} & \multirow{2}{*}{$\begin{array}{c}\mathbf{k} \\
\left(d^{-1}\right)\end{array}$} & \multirow{2}{*}{$\begin{array}{l}\eta_{T S} \\
(\%)\end{array}$} & \multirow{2}{*}{$\begin{array}{l}\text { पCOD } \\
(\%)\end{array}$} & \multirow{2}{*}{$\begin{array}{c}\mathbf{Q}_{\mathrm{bg}} \\
\left(L L^{-1} \cdot d^{-1}\right)\end{array}$} & \multirow{2}{*}{$\begin{array}{c}\mathbf{y}_{\mathrm{CO} 2} \\
(\%)\end{array}$} \\
\hline & Initial & Final & & & & & & \\
\hline $\mathrm{R}_{\mathrm{w}}, 1$ & 4.31 & 4.2 & $26 \%$ & 0.019 & 53 & 42 & 0.15 & 91 \\
\hline $\mathrm{R}_{\mathrm{w}}, 2$ & 4.21 & 4.06 & $10 \%$ & 0.038 & 49 & 70 & 0.07 & 92 \\
\hline $\mathrm{R}_{\mathrm{w}}, 3$ & 4.53 & 4.23 & $9 \%$ & 0.031 & 38 & 61 & 0.08 & 87 \\
\hline $\mathrm{R}_{\mathrm{w}}, 4$ & 4.16 & 5.13 & $12 \%$ & 0.025 & 41 & 54 & 0.14 & 97 \\
\hline $\mathrm{R}_{\mathrm{w}}, 5$ & 5.69 & 6.19 & $9 \%$ & 0.023 & 51 & 51 & 0.08 & 92 \\
\hline Av. & 4.58 & 4.76 & $13.3 \%$ & 0.028 & 46.4 & 55.6 & 0.1 & 91.8 \\
\hline $\mathrm{R}_{\mathrm{wL} 7}, 1$ & 4.29 & 7.06 & $24 \%$ & 0.039 & 48 & 50 & 0.27 & 91 \\
\hline $\mathrm{R}_{\mathrm{wL7}, 2}$ & 4.31 & 6.2 & $25 \%$ & 0.022 & 58 & 51 & 0.37 & 93 \\
\hline $\mathrm{R}_{\mathrm{wL7}, 3}$ & 4.75 & 6 & $20 \%$ & 0.024 & 49 & 55 & 0.27 & 91 \\
\hline $\mathrm{R}_{\mathrm{wL} 7,4}$ & 6 & 6 & $17 \%$ & 0.021 & 53 & 46 & 0.42 & 89 \\
\hline $\mathrm{R}_{\mathrm{wL} 7}, 5$ & 5.6 & 6.56 & $18 \%$ & 0.059 & 56 & 42 & 0.39 & 86 \\
\hline Av. & 4.99 & 6.36 & $20.8 \%$ & 0.033 & 52.8 & 48.8 & 0.344 & 90 \\
\hline $\mathrm{R}_{\mathrm{wL}, 1}$ & 5.13 & 3.7 & $3 \%$ & 0.024 & 47 & 56 & 0.09 & 100 \\
\hline $\mathrm{R}_{\mathrm{wL}}, 2$ & 5.3 & 4.5 & $10 \%$ & 0.019 & 59 & 45 & 0.15 & 100 \\
\hline $\mathrm{R}_{\mathrm{wL}, 3}$ & 4.9 & 4.2 & $4 \%$ & 0.019 & 52 & 38 & 0.13 & 100 \\
\hline Av. & 5.11 & 4.13 & $5.4 \%$ & 0.021 & 53 & 46 & 0.123 & 100 \\
\hline
\end{tabular}

In all experiments $\mathrm{pH}$ seems to have no effect on solids destruction, COD removal and the dissolution constant but it impacted on VFA [21, 22] and methane production. In $\mathrm{R}_{\mathrm{wL}}$ reactor with $\mathrm{pH}$ values around 4.13 only carbon dioxide was produced, while $10 \% \mathrm{CH}_{4}$ in biogas is obtained in reactors with external buffer $\mathrm{R}_{\mathrm{wL}}\left(\mathrm{pH}\right.$ 6.36) and $\mathrm{R}_{\mathrm{w}}$ where $\mathrm{pH}$ increases to 6.12 without external buffer, production of $\mathrm{CH}_{4}$ was less $(8 \%)$. It is reported elsewhere, [11] that $\mathrm{pH}$ affects the hydrolysis first-order constant $(\mathrm{k})$ and that high TS removal and COD are enhanced by neutral $\mathrm{pH}$ [15]. The opposite was found in this work.

It is only acidogenesis and methanogenesis that are affected by $\mathrm{pH}$ values, although Dinamarca et al., obtained more than $25 \mathrm{~g} \mathrm{VFA:}^{-1}$ in $\mathrm{pH}$ uncontrolled reactors [4].

As hydrolysis takes place, VFA increase while $\mathrm{pH}$ decreases to their pKa values; if higher than 6 , acidogenesis will be faster than in treatments with lower $\mathrm{pH}$ values thus obtaining better COD removal, similar result reported by Elango et al. But on the other hand, there is no significant difference on solids destruction. Under neutral conditions (RwL7), for the five batches evaluated in each BATB reactor, it was possible to obtain high VFA formation (more than 20\% of degraded COD), more than $49 \%$ solids and $42 \%$ COD reduction ( $\eta_{T S}$ and $\eta_{C O D}$ ) and biogas production of more than $0.3 \mathrm{~L}_{b g} \mathrm{~L}^{-1} \mathrm{~d}^{-1}$ with $\mathrm{y}_{\mathrm{CH}}$ greater than $7 \%$ with solids retention times of around 33 days.

\section{Leachate treatment in a UASB reactor.}

Figure 3 shows biogas production and COD removal of the BATB reactor leachates diluted with wastewater from the university campus. There were five runs at different hydraulic residence times (HRT), 1, 1, 1.5, 1.25, and $1.25 \mathrm{~d}$ and different inlet concentrations. The first run was a start up period at 1 day HRT and SUo $=20 \mathrm{~g} \cdot \mathrm{L}^{-1}$ (and is not considered in the regression), (Figure 4). At the highest loading rates (run II), there are an accumulation of VFA, mainly propionate, which is the most inhibitory for the methanogenic activity, $[12,13,23]$ so the HRT was increased to 1.5 days to bring down the load (Bv).

The leachates treated in UASB reactor, at loading rates similar to those reported by [16, 17], showed removal efficiencies of COD, over $90 \%$, without the addition of nutrients to the leachate and methane composition in the biogas increased to $80 \%$. 


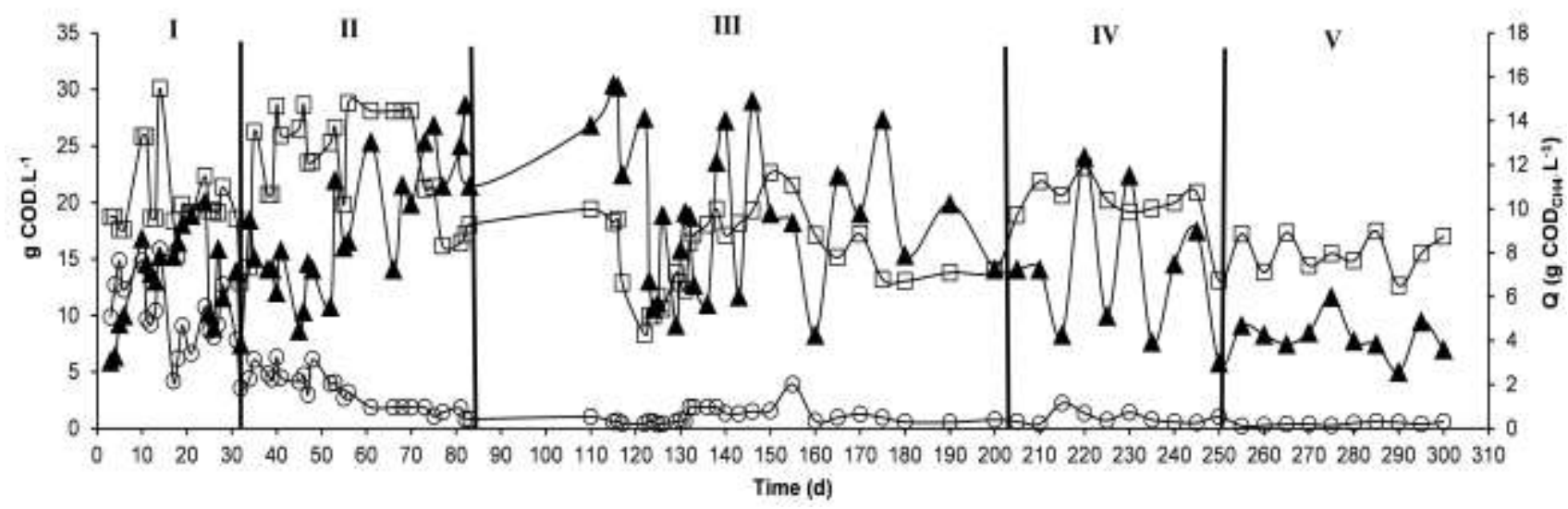

Figure 3. Treatment of the BATBR leachate (diluted with waste water) in a UASB reactor $\left(\Delta Q_{\mathrm{cH} 4, \square} S_{\mathrm{Uo}}, \circ \mathrm{S}_{\mathrm{U} 1 \text {. }}\right.$. Stage, HRT: I, 1 d, II, 1 d, III, 1.5 d, IV \&V, 1.25 d)

Figure 4 shows the semi steady state values (4 to 5 retention times long) of runs I to $\mathrm{V}$, with organic loading rates of 12.5 to $28\left(\mathrm{~g} . \mathrm{L}^{-1} . \mathrm{d}^{-1}\right)$; to highest organic loading rate, increased methane production and COD removal. This means that with $1: 5$ to $1: 8$ dilutions with municipal wastewater would be enough to get at suitable removal efficiency in UASB reactors. The gas production in terms of the COD equivalent is also shown indicating a $50 \%$ methane recovery.

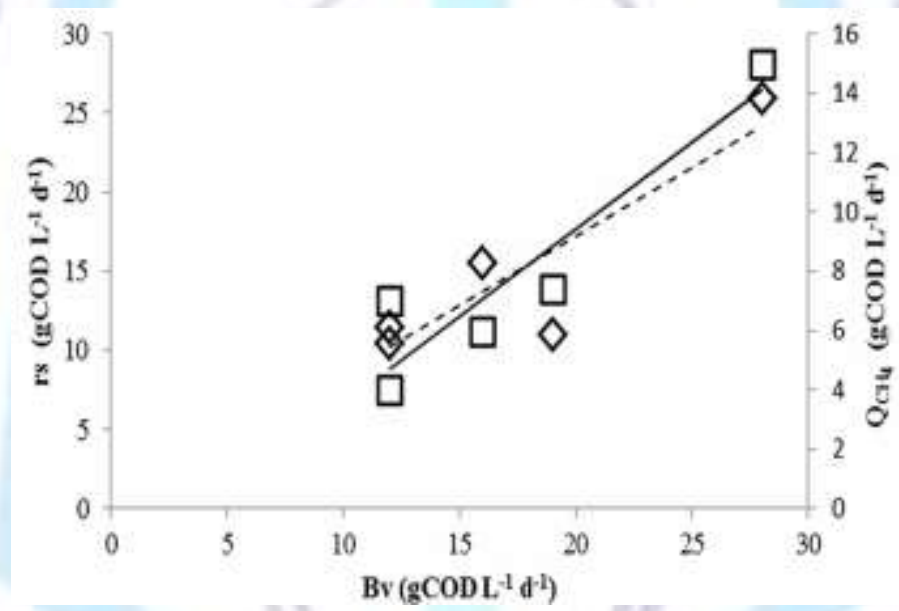

Figure 4. COD removal rate $\left(\diamond \mathrm{r}_{\mathrm{S}}\right)$ and methane production $\left(\square \mathrm{Q}_{\mathrm{CH} 4-\mathrm{COD}}\right)$ as a function of the organic loading rate $\left(B_{v}\right)$ in a UASB reactor treating BATBR leachates diluted in MWW.

\section{CONCLUSIONS}

Two phases anaerobic digestion to treat OFMSW; the hydrolytic-acidogenic phase in a BATB reactor speeds up the dissolution of organic solids, reducing $50 \%$ of total solids and COD in less than 30 days and produces a leachate with high COD concentrations. Leachate recirculation and $\mathrm{pH}$ do not influence hydrolysis rate or efficiency of solids but only VFA and methane production are enhanced with $\mathrm{pH}$ higher than 4.8. These results suggest that there is no need to adjust $\mathrm{pH}$ or recycle leachate as reported elsewhere because there is no improvement in solids destruction but enhances methane production, which is not desirable at this stage, because it would be difficult to collect it in a continuously fed reactor.

A first order dissolution equation describes the profile of the organic matter recovered in the leachate proving that there is no difference in the $\mathrm{k}$ values validating that no $\mathrm{pH}$ control in needed thus giving way to a more simple process than previously reported.

The leachate can be treated, diluted with municipal wastewaters, in a UASB reactor up to OLR of $28 \mathrm{~g} \mathrm{COD} \mathrm{L}^{-1} \mathrm{~d}^{-1}$ and producing $11 \mathrm{~g} \mathrm{CH}_{4-\mathrm{COD}} \mathrm{L}^{-1} \cdot \mathrm{d}^{-1}$. Considering that a normal loading rate for MWW treatment is $2 \mathrm{~g} \mathrm{~L}^{-1} \cdot \mathrm{d}^{-1}$, there is enough capacity in MWW anaerobic reactors to treat these wastes. Overall, the process yields $0.2 \mathrm{~kg} \mathrm{CH}_{4-\mathrm{CoD}} \mathrm{kg}^{-1} \mathrm{TS}$ fed $(0.63$ $\mathrm{kW}^{*} \mathrm{hr} \mathrm{kg}^{-1} \mathrm{TS}$ fed). 


\section{REFERENCES}

[1] INEGI, 2012. Estadística sobre generación de residuos sólidos en México. Publicaciones 2012: www.inegi.gob.mx (30 Septiembre, 2013).

[2] Ward, A.J., Hobbs, P.J., Holliman, P.J., Jones, D.L. Optimization of the anaerobic digestion of agricultural resources. Bioresour. Technol. 99, 7928-7940. (2008)

[3] Viéitez, E.R., Ghosh, S. Biogasification of solid waste by two-phase anaerobic fermentation. Biom. \& bioener., 16: 299-309 (1999)Tavel, P. 2007 Modeling and Simulation Design. AK Peters Ltd.

[4] Dinamarca S., Aroca G., Chamy R., Guerrero L. The influence of $\mathrm{pH}$ in the hydrolytic stage of anaerobic digestion of the organic fraction of urban solid waste. Water Sci.\& Technol. 48,6: 249-254 (2003)

[5] Chungh, S., Pullammanappallil, P., Rudolph V. Effect of recirculated leachate volume on MSW degradation. Waste Manag. and Res. 6,16: 564-573 (1998).

[6] Šan, I., Onay, T.T. Impact of various leachate recirculation regimes on municipal solid waste degradation. J. Hazard. Mater. 87, 259-271. (2001)

[7] Zhang, B., He, P.J., Lu, F., Shao, L.M., Wang, P. Extracellular enzyme activities during regulated hydrolysis of highsolid organic wastes. Water Res. 41, 4468- 4478. (2007)

[8] Chen, L. Jiang W.Z., Kitamura, Y., Li, B.M. Enhancement of hydrolysis and acidification of solids organic waste by rotational drum fermentation system with methanogenic leachate recirculation. Bioresour. Technol. 98, 2194-2200 (2007)

[9] Demirer, G.N., Chen, S. Anaerobic biogasification of undiluted dairy manure in leaching bed reactors. Waste Manag. 28, 112-119 (2008)

[10] Xu S. Y., Lam H. P., Karthikeyan P.O., Wong J. W. Optimization of food waste hydrolysis in leach bed coupled with methanogenic reactor: Effect of pH and bulking agent. Bioresour Technol. 102 3702-3708 (2011)

[11] Mata-Alvarez J., Macé, S., Llabrés, P. Anaerobic digestion of organic solid wastes. An overview of research achievements and perspectives. Bioresour. Technol. 74, 3-16 (2000).

[12] Borzacconi, L., Lopez, I. and Anido, C. Hydrolysis constant and VFA inhibitionin acidogenic phase of MSW anaerobic degradation, Water Sci. Tech., Vol. 36, pp.6-7 (1997).

[13] Shin, H. Performance of UASB Reactor Treating leachate from acidogenic fermenter in the two-phase anaerobic digestion of food waste. Water Res. 35, 14: 3441-3447 (2001).

[14] Zeeman, G., Palenzuela Rollon, A., Sanders, W., Miron, Y. and Lettinga, G. Anaerobic hydrolysis and acidification of lipids, proteins and carbohydrates under methanogenic and acidogenic conditions, in Mata-Alvarez, J., Tilche, B. and Cecchi, F. (Eds.): Proceedings of the Second International Symposium on Anaerobic Digestion of Solid Wastes, Grafiques 92, Barcelona, Vol. 2, pp.21-24 (1999).

[15] Elango, D., Pulikesi, M., Baskaralingam, P., Ramamurthi V., Sivanesan, S. Production of biogas from municipal solid waste with domestic sewage. J. of Hazard. Mater. 141, 301-304 (2007).

[16] Torres, P., Rodríguez, J., Barba, E., Morán, A. y Narváez, J.,. Tratamiento anaerobio de lixiviados en reactores UASB. Ing. \& Desarrollo. 18: 62 (2005)

[17] Macias-Corral, M., Samani Z., Hanson, A., Smith, G., Funk, P., Yu, H., Longworth, J. Anaerobic digestion of municipal solid waste and agricultural waste and the effect of co-digestion with dairy cow manure. Bioresour. Technol. 99, 8288-8293 (2008)

[18] Tran, L., Palenzuela, A., Nakasaki, K. Anaerobic digestion of Organic Fraction of Municipal Solid Waste (OFMSW) in two-phase system. Int. J. Environ and Waste Manag, Vol. 9, Nos. 1/2, (2012).

[19] APHA, AWWA, WPFC. Standard Methods for the Examination of water and wastewater. 17 th. Ed. Am. Pub. Health Assoc. USA. (2005).

[20] Hernández-Becerril, Ma. C., Márquez-Benavides, L., González-Pérez, D.J., \& Buenrostro-Delgado, O. The effect of moisture on the anaerobic degradation of municipal solid waste from Metepec (México). Waste Manag. 28, S14-S20 (2008).

[21] Zhang B., Zhang L-L., Zhang S-C, Shi H-Z. £ Cai W-M. The influence of pH on the hydrolysis and acidogenesis of kitchen wastes in teo-phase anaerobic digestion. Environ. Technol. 6, 329-339 (2005).

[22] Jiang Y., Heaven S., Banks C.J. Strategies for stable anaerobic digestion of vegetable waste. Renew Energy 44, 206-214 (2012).

[23] Wang, J., Shen, D., Xu, Y. Effect of acidification percentage and volatile organic acids on the anaerobic biological process in simulated landfill bioreactors. Process Biochem. 41, 1677-1681 (2006). 


\section{ISSN 2348-6201}

\section{Author' biography with Photo}

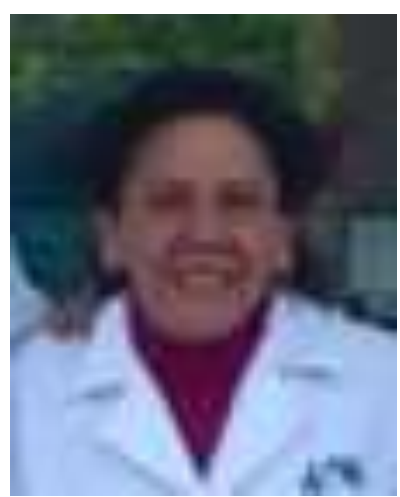

Florina Ramírez Vives her Ph D in Biological sciences, Iztapalapa Metropolitan University Autonomy. She works in the Department of Biotechnology, in the area of microbiology, with expertise in microbiology, ecology and anaerobic physiology as well as in water treatment and solid waste by anaerobic digestion. She has published more than 20 articles and reports indexed extensively. She has directed doctoral thesis, masters and specialization in her university and other educational institutions. 